Acta vet. scand. $1961,2,68-84$.

From the Departments of Medicine for Non-Ruminants, Roentgenology, and Clinical Biochemistry, Royal Veterinary College, Stockholm.

\title{
RENAL CORTICAL HYPOPLASIA IN DOGS \\ A CLINICAL STUDY ON URAEMIA AND SECONDARY HYPERPARATHYREOIDISM
}

By

F. Persson, S. Persson and Å. Åsheim

The clinical picture of renal cortical hypoplasia in the dog has not been described earlier. Patho-anatomically, it was described by Krook in 1957. Because of its character of chronic nephropathy a study of its clinical as well as patho-anatomical picture will largely be a study of the uraemia in dogs. The disease affects mainly cocker-spaniels of both sexes, greyish black and black as well as brown dogs. It consists in a congenital (Dyrendahl and Henricson) hypoplasia of the cortex of both kidneys. Normal kidneys have a very great reserve capacity. About $75 \%$ of the nephrons can be incapable of functioning before renal insufficiency develops. The cortical hypoplasia probably leads to a marked reduction of the number of glomeruli. The reserve capacity, which is very low in these cases, will thus be overstrained as the organism grows. The symptoms of the disease manifest themselves at the age of $1 / 2$ to 2 years with a distinct accumulation of cases around the age of 12 months. The duration of the disease varies from a week or two to several months. The first symptoms are polyuria with accompanying polydipsia, intermittent anorexia and emaciation. A generalized anaemia manifested by pale mucous membranes occurs in most cases. In some cases a feature of the history is that the dog shows tenderness at the jaws on eating. These animals of ten have a flexible rubberlike mandible. Tonic-clonic spasms are more seldom seen. In advanced stages vomiting and diarrhoea, apathy, dehydration, subnormal temperature and death occur.

Krook points out that in renal cortical hypoplasia in dogs as 
well as in all chronic nephropathies, the non-renal pathological changes can be divided into three groups:

1. Changes caused by the uraemia;

2. Changes caused by secondary hyperparathyreoidism;

3. Changes caused by hypertension.

The most important uraemic changes are caused by the retention of nitrogenous products in the blood. A chronic catarrhal haemorrhagic gastritis and a catarrhal enteritis are seen. An ammoniacal odour from the stomach can often be noticed.

The secondary hyperparathyreoidism is manifested by the renal osteopathy, which, accordingly, represents a compensatory mobilisation of calcium from the bone-tissue under the influence of parathormone.

As regards the renal hypertension, its occurrence in dogs is a subject of controversy. The strongest supporting evidence of the occurrence of renal hypertension is considered to be hypertrophy of the left side of the heart often seen at autopsy of cases with renal lesions (Nieberle and Cohrs, 1954).

The work presented here deals with that part of the clinical manifestation of renal cortical hypoplasia in dogs which concerns the uraemia and the secondary hyperparathyreoidism. Results will be reported from the following clinical investigations:

1. Urine analyses;

2. Blood analyses, including determination of the electrolytes sodium, potassium, calcium and phosphorus;

3. Inulin and PAH clearance;

4. Intravenous urography;

5. X-ray of the bones.

\section{MATERIAL}

The investigations were carried out on two different materials, partly on dogs admitted to the medical clinic at the Royal Veterinary College over the years 1955-1960, and partly on experimental dogs. All the dogs were cocker-spaniels.

The first material comprised 16 dogs, 8 of each sex. Their ages ranged from 8 to 18 months. Some of the dogs were admitted at such an advanced stage of the disease that there was no time for a complete investigation. Fourteen of the 16 dogs were subjected to autopsy, at which the diagnosis was verified. 
The second material consisted of puppies obtained from parents which earlier had born puppies with renal cortical hypoplasia. In this material, which comprised 21 dogs from 5 litters, the disease manifested itself in 3 cases, all female dogs. These three died at an age of $10,16 \frac{1}{2}$ and $17 \frac{1}{2}$ months, respectively. Among those without manifestations of the disease 2 died of other causes. At autopsy of these two cases it was established that hypoplasia was not present. Of the remaining $16 \operatorname{dogs} 11$ were killed and subjected to autopsy, at which no evidence of hypoplasia was found. The other 5 are, at the time of writing, alive and in good health. All these 21 dogs were subjected to continuous clinical investigations. The values from continuous renal clearance determinations in the $\mathbf{1 6}$ healthy dogs, as well as from continuous blood-pressure and serum-electrolyte determinations, will be reported elsewhere.

\section{METHODS}

Urine analyses were carried out with respect to specific gravity, protein, reducing substance, haemoglobin, bilirubin and sediment. The blood analyses concerned red-cell count, whitecell count, erythrocyte-sedimentation rate, haemoglobin, haematocrit and non-protein nitrogen. The sodium and potassium content in blood-serum was determined by means of flame photometry ("EEL"). Calcium was determined by Clark and Collip's modification (1925) of Kramer and Tisdall's method (1921). Inorganic phosphorus was determined by the method of Taussky and Shorr (1953). In the renal clearance tests, which were done under anaesthesia with "Mebumal"1), inulin and PAH were used for determination of glomerular filtration and effective renal plasma flow, respectively. The technique and the analytical methods applied in these determinations have been described and discussed in detail in an earlier publication (As sheim, Persson and Persson). In the clinical material renal clearance determinations were done in 2 cases only ( $888 / 56$ and $313 / 58$ ).

1) The formula of "Mebumal" is as follows:

5-ethyl-5(1-methylbutyl)-malonylcarbamide (pentobarbitone) $\quad 1.8 \mathrm{~g}$

Pentobarbitone sodium

$4.0 \mathrm{~g}$

Urethane

$25.0 \mathrm{~g}$

Spir. conc.

$15.0 \mathrm{~g}$

Glycerin

$12.5 \mathrm{~g}$

Aq. steril.

ad $100 \mathrm{ml}$ 
Intravenous urography was performed after injection of 15$20 \mathrm{ml}$ of $35 \%$ Umbradil (diethanolamine salt of diodone; diodone $=3: 5$-di-iodo-4-pyridone-N-acetic acid). By temporarily lowering the arterial blood pressure in the dogs to approximately 50 $\mathrm{mm} \mathrm{Hg}$, using a method with inhalation of amyl nitrite, a good nephrographic effect could be achieved. It was found impossible, however, to reveal a cortical hypoplasia by inspection of the films thus obtained.

$\mathrm{X}$-ray of the bones was performed, special interest being deroted to the bones of the upper and the lower jaw.

\section{RESULTS}

Urine analyses: The first clinical symptom of renal cortical hypoplasia is proteinuria which persists and increases in intensity. Table 1 records the ages at onset of the different phases of the disease, as observed in the three affected experimental dogs.

Tab le 1.

Ages at the first appearance of proteinuria, beginning rise of N.P. N. in the blood, and death.

\begin{tabular}{|c|c|c|c|}
\hline Dog no. & Proteinuria & Rise of N.P. N. & Death \\
\hline I : 1 & 4 months & 15 months & $161 / 2$ months \\
\hline II $: 4$ & 4 & 8 & 10 \\
\hline $\mathrm{V}: 7$ & 4 & 16 & $171 / 2$ \\
\hline
\end{tabular}

All the 19 dogs with renal cortical hypoplasia had highdegree proteinuria. In 5 cases glycosuria was also present. By checking of the blood-sugar level in these cases diabetes as the cause could be excluded. A hyposthenuria, which at more marked manifestations of the disease changed into isosthenuria, was seen in all the cases. Specific gravity of the urine both in spontaneous specimens and after 24 hours of no water intake, was in all cases around 1.010 .

Blood analyses: The blood analyses gave pathological values as regards total red-cell count, haemoglobin, non-protein nitrogen, potassium, calcium and phosphorus. These values from the clinical material are listed in Table 2. 
Table 2.

Blood examinations from the clinical material. The italicized values were used for statistical analysis.

\begin{tabular}{|c|c|c|c|c|c|c|c|c|c|}
\hline Dog & Sex & $\begin{array}{c}\text { Date } \\
\text { of } \\
\text { death }\end{array}$ & $\begin{array}{c}\text { Date of } \\
\text { taking } \\
\text { specimen }\end{array}$ & $\begin{array}{c}\text { Non-pro- } \\
\text { tein } \\
\text { nitrogen } \\
\mathrm{mg} / 100 \mathrm{ml}\end{array}$ & $\begin{array}{c}\text { Red } \\
\text { cells } \\
1000000 \\
/ \text { c. } \mathbf{m m} \text {. }\end{array}$ & $\begin{array}{c}\text { Haemo- } \\
\text { globin } \\
\text { g/ } \\
100 \mathrm{ml}\end{array}$ & $\begin{array}{l}\text { Calcium } \\
\mathrm{mg} / \\
100 \mathrm{ml}\end{array}$ & $\begin{array}{c}\text { Phos- } \\
\text { phorus } \\
\mathrm{mg} / \\
100 \mathrm{ml}\end{array}$ & $\begin{array}{l}\text { Potassi- } \\
\text { um } \mathrm{mg} / \\
100 \mathrm{ml}\end{array}$ \\
\hline $286 / 55$ & 우 & $8 / 4$ & $\begin{array}{l}4 / 4 \\
5 / 4 \\
6 / 4\end{array}$ & $\begin{array}{l}118 \\
136 \\
167\end{array}$ & & & & & \\
\hline $888 / 56$ & $q$ & $25 / 10$ & $21 / 10$ & 190 & 2.4 & 5.9 & 11.4 & 24.0 & 25.3 \\
\hline $920 / 56$ & $0^{x}$ & $30 / 10$ & $30 / 10$ & 300 & 6.3 & 11.0 & 6.2 & 49.0 & 33.5 \\
\hline $1040 / 56$ & $0^{x}$ & $5 / 12$ & $5 / 12$ & 170 & 5.2 & 12.5 & 6.3 & 11.4 & 10.5 \\
\hline $316 / 57$ & $0^{x}$ & $28 / 3$ & $28 / 3$ & 400 & & 12.5 & 4.3 & 63.6 & 15.3 \\
\hline $318 / 57$ & 우 & $13 / 4$ & $13 / 4$ & 290 & & & 7.1 & & \\
\hline $1109 / 57$ & q & $17 / 11$ & $13 / 11$ & 315 & 4.2 & 11.0 & 6.8 & 37.3 & 16.6 \\
\hline $313 / 58$ & $0^{x}$ & $15 / 4$ & $\begin{array}{l}10 / 4 \\
11 / 4 \\
14 / 4 \\
15 / 4\end{array}$ & $\begin{array}{l}96 \\
90\end{array}$ & 5.2 & 13.9 & $\begin{array}{r}11.4 \\
10.9 \\
9.5 \\
9.9\end{array}$ & $\begin{array}{r}8.4 \\
11.4 \\
14.7 \\
20.4\end{array}$ & 22.2 \\
\hline $561 / 58$ & $q$ & $7 / 7$ & $4 / 7$ & 110 & 6.2 & 13.2 & 14.3 & & 19.1 \\
\hline $604 / 58$ & $\stackrel{+}{+}$ & $22 / 7$ & $18 / 7$ & 300 & 4.5 & 13.9 & 8.5 & 44.0 & 21.8 \\
\hline J 58 & 우 & & $\begin{array}{c}30 / 9 \\
2 / 10\end{array}$ & $\begin{array}{l}170 \\
119\end{array}$ & & & $\begin{array}{l}6.7 \\
6.6\end{array}$ & $\begin{array}{l}28.2 \\
30.9\end{array}$ & \\
\hline $899 / 59$ & q & $12 / 10$ & $9 / 10$ & 135 & 4.5 & 11.8 & & & 22.2 \\
\hline Hampus & $a^{x}$ & & $\begin{array}{l}12 / 12 \\
13 / 12 \\
17 / 12\end{array}$ & 330 & 3.8 & 10.9 & $\begin{array}{l}5.8 \\
5.5 \\
4.8\end{array}$ & $\begin{array}{l}41.8 \\
32.7 \\
56.3\end{array}$ & 17.6 \\
\hline $160 / 60$ & $\sigma^{x}$ & $2 / 3$ & $\begin{array}{l}26 / 2 \\
27 / 2\end{array}$ & 106 & 4.0 & 9.2 & 7.3 & 16.6 & 17.6 \\
\hline & & & $29 / 2$ & 160 & & & 8.9 & 21.9 & 19.5 \\
\hline & & & $3 / 3$ & 125 & & & 11.1 & 35.0 & 24.6 \\
\hline E 60 & $\sigma^{x}$ & $5 / 3$ & $\begin{array}{l}2 / 3 \\
4 / 3\end{array}$ & $\begin{array}{r}56 \\
100\end{array}$ & & 13.2 & $\begin{array}{r}9.6 \\
11.3\end{array}$ & $\begin{array}{l}20.0 \\
25.6\end{array}$ & $\begin{array}{l}19.5 \\
17.6\end{array}$ \\
\hline N 49 & $\sigma^{x}$ & $15 / 6$ & $\begin{array}{l}22 / 3 \\
24 / 3\end{array}$ & $\begin{array}{r}90 \\
122\end{array}$ & 5.2 & $\begin{array}{l}13.5 \\
10.5\end{array}$ & $\begin{array}{l}8.7 \\
7.9\end{array}$ & $\begin{array}{l}17.0 \\
21.2\end{array}$ & $\begin{array}{l}17.6 \\
17.6\end{array}$ \\
\hline & & & $4 / 4$ & 95 & 3.5 & 11.0 & 9.8 & 16.8 & 20.3 \\
\hline & & & $10 / 4$ & 104 & 4.0 & 10.9 & 8.5 & 14.0 & 19.5 \\
\hline & & & $19 / 4$ & 89 & 4.0 & 9.9 & 10.0 & 16.0 & 23.0 \\
\hline & & & $6 / 5$ & 76 & 3.0 & 8.2 & 6.9 & 17.0 & 20.3 \\
\hline & & & $14 / 6$ & 180 & 2.8 & 7.1 & 8.4 & 27.8 & 22.7 \\
\hline
\end{tabular}

The values obtained by blood analyses in the three experimental dogs (nos. I : 1, II : 4, V:7) which comprise a great number of observations at different times, are set out in Table 3 . 
T a b l e 3 .

Blood examinations from the three hypoplastic experimental dogs. The italicized values were used for statistical analysis.

\begin{tabular}{|c|c|c|c|c|c|c|c|c|}
\hline Dog & $\begin{array}{c}\text { Age } \\
\text { weeks }\end{array}$ & $\begin{array}{l}\text { Sodium } \\
\mathrm{mg} / 100 \mathrm{ml}\end{array}$ & $\begin{array}{l}\text { Potassium } \\
\mathrm{mg} / 100 \mathrm{ml}\end{array}$ & $\underset{\mathrm{mg} / 100 \mathrm{ml}}{\text { Calcium }}$ & $\begin{array}{c}\text { Phos- } \\
\text { phorus } \\
\text { l mg/ } \\
100 \mathrm{ml}\end{array}$ & $\begin{array}{c}\text { Non- } \\
\text { protein } \\
\text { nitrogen } \\
\mathrm{mg} / \\
100 \mathrm{ml}\end{array}$ & $\begin{array}{c}\text { Red } \\
\text { cells } \\
1000000 \\
\text { /c. } \mathbf{m m} .\end{array}$ & $\begin{array}{c}\text { Haemo- } \\
\text { globin } \\
\text { g/100 ml }\end{array}$ \\
\hline \multirow[t]{15}{*}{ I : 1} & 15 & 350 & 18.0 & - & 7.0 & 23 & 6.2 & 12.5 \\
\hline & 22 & 337 & - & 7.7 & 6.2 & 30 & 6.5 & 13.6 \\
\hline & 25 & 332 & 14.5 & 10.0 & 6.1 & 33 & 5.2 & 14.0 \\
\hline & 32 & 323 & 13.5 & 9.9 & 5.5 & 34 & 4.8 & 14.2 \\
\hline & 40 & 330 & 16.0 & 10.5 & 4.5 & 36 & 5.8 & 13.5 \\
\hline & 49 & 320 & 15.3 & 7.5 & 5.0 & 38 & 5.4 & 12.2 \\
\hline & 65 & 325 & 18.0 & 9.7 & 11.0 & 106 & & \\
\hline & $65^{1 / 2}$ & 336 & 16.5 & 9.5 & 28.4 & 151 & & \\
\hline & 66 & 350 & 13.5 & 8.6 & 33.5 & 195 & 4.6 & 15.3 \\
\hline & $66^{1 / 2}$ & 340 & 9.3 & 7.9 & 33.5 & 148 & & \\
\hline & 67 & $(296)$ & 11.2 & 7.0 & 32.1 & - & & \\
\hline & 68 & 326 & 13.8 & 9.4 & 16.0 & 100 & & \\
\hline & 69 & - & 15.0 & 9.0 & 21.0 & 130 & & \\
\hline & 71 & 340 & 17.5 & 7.1 & 27.5 & 157 & & \\
\hline & 73 & 320 & 12.1 & 7.9 & 25.5 & 175 & & 7.4 \\
\hline \multirow[t]{6}{*}{ II : 4} & 16 & 330 & 14.7 & 9.6 & 8.0 & & 5.6 & 13.8 \\
\hline & 18 & 320 & 13.3 & 10.2 & 4.2 & 33 & 6.8 & 16.8 \\
\hline & 26 & (410) & 12.2 & 9.9 & 4.4 & 67 & 4.8 & 13.8 \\
\hline & 34 & 355 & 16.5 & 9.9 & 4.5 & 87 & 6.3 & 16.5 \\
\hline & 44 & 307 & 14.8 & 10.4 & 27.3 & 85 & 7.1 & 16.7 \\
\hline & 46 & 315 & 14.6 & 6.1 & 51.0 & 160 & 7.2 & 16.8 \\
\hline \multirow[t]{9}{*}{ V: 7} & $141 / 2$ & 336 & 15.6 & 10.4 & 8.1 & 29 & 5.7 & 10.3 \\
\hline & 26 & 338 & 15.7 & 11.7 & 4.4 & 33 & & \\
\hline & 34 & & & 10.5 & 5.8 & 27 & & 14.2 \\
\hline & 43 & & & 10.1 & 5.2 & 32 & 5.9 & 14.5 \\
\hline & 71 & 329 & 17.2 & 9.5 & 12.9 & 105 & 5.9 & 15.7 \\
\hline & $711 / 2$ & 350 & 19.5 & 10.3 & 10.8 & 78 & & \\
\hline & 72 & 334 & 21.5 & 9.9 & 13.2 & 106 & & \\
\hline & 76 & & & 6.5 & 30.0 & 236 & & \\
\hline & 77 & 338 & 19.1 & 4.7 & 51.8 & 610 & & \\
\hline
\end{tabular}

From the continuous determinations of serum-electrolytes, red-cell counts and haemoglobin in the $\mathbf{1 6}$ healthy experimental dogs one value from each dog taken at the age of about 12 months, was selected for statistical analysis. The results of the latter will be seen in Table 4 in which the values for healthy dogs and hypoplastic dogs are recorded. 
T a ble 4.

Serum-electrolytes, red cells and haemoglobin content in blood from normal dogs and dogs with renal cortical hypoplasia.

\begin{tabular}{|c|c|c|c|c|c|c|}
\hline & $\begin{array}{l}\text { Sodium } \\
\mathrm{mg} / 100 \mathrm{ml}\end{array}$ & $\begin{array}{l}\text { Potassium } \\
\mathrm{mg} / 100 \mathrm{ml}\end{array}$ & $\begin{array}{l}\text { Calcium } \\
\mathrm{mg} / 100 \mathrm{ml}\end{array}$ & $\begin{array}{l}\text { Phosphorus } \\
\mathrm{mg} / 100 \mathrm{ml}\end{array}$ & $\begin{array}{c}\text { Red cells } \\
1000000 / \\
\text { c. } \mathrm{mm} \text {. }\end{array}$ & $\begin{array}{c}\text { Haemo- } \\
\text { globin } \\
\mathrm{g} / 100 \mathrm{ml}\end{array}$ \\
\hline \multicolumn{7}{|c|}{ Normal dogs } \\
\hline Number of dogs & 16 & 16 & 16 & 16 & 16 & 16 \\
\hline Range & 318-357 & 13.5-19.9 & $7.8-11.4$ & $3.3-5.8$ & $5.1-7.9$ & $12.0-17.8$ \\
\hline Mean values & 336 & 16.3 & 10.1 & 4.7 & 6.2 & 14.9 \\
\hline $\begin{array}{l}\text { Standard } \\
\text { deviation }\end{array}$ & 12 & 2.02 & 1.2 & 0.8 & 0.9 & 1.9 \\
\hline $\begin{array}{l}\text { Standard error } \\
\text { of mean }\end{array}$ & 3 & 0.51 & 0.31 & 0.21 & 0.23 & 0.48 \\
\hline \multicolumn{7}{|c|}{ Renal cortical hypoplasia } \\
\hline Number of dogs & & 16 & 17 & 15 & 14 & 16 \\
\hline Range & & $10.5-33.5$ & $4.3-14.3$ & 11.4-63.6 & 2.4-7.2 & $5.9-16.8$ \\
\hline Mean values & & 19.9 & 7.9 & 36.2 & 4.8 & 11.6 \\
\hline $\begin{array}{l}\text { Standard } \\
\text { deviation }\end{array}$ & & 5.65 & 2.8 & 15.8 & 1.3 & 3.7 \\
\hline $\begin{array}{l}\text { Standard error } \\
\text { of mean }\end{array}$ & & 1.41 & 0.70 & 4.70 & 0.35 & 0.93 \\
\hline
\end{tabular}

In the comparison of the values between healthy dogs and sick dogs given in Table 4, Student's t-test was used for determining the degree of significance. The result will be seen in Table 5 in which the P-values are given.

T a b l e 5 .

P-values obtained from Student's t-test at comparison of serum-electrolytes, red-cell count and haemoglobin concentration in the blood between normal dogs and hypoplastic dogs.

\begin{tabular}{ll}
\hline Potassium & $0.05>\mathrm{P}>0.01$ \\
Calcium & $0.01>\mathrm{P}>0.001$ \\
Phosphorus & $0.001>\mathrm{P}$ \\
Red-cell count & $0.01>\mathrm{P}>0.001$ \\
Haemoglobin & $0.01>\mathrm{P}>0.001$ \\
\hline
\end{tabular}

The clearance values for głomerular filtration (GFR), effective renal plasma flow (RPF) and $\mathrm{C}_{\mathrm{I}_{n}} / \mathrm{C}_{\mathrm{PAH}}$ ratio (FF), measured at various times in the three experimental dogs, are recorded in Table 6. 
Table 6 .

Glomerular filtration $\left(\mathrm{C}_{\mathrm{In}}\right)$, effective renal plasma flow $\left(\mathrm{C}_{\mathrm{PAH}}\right)$, filtration fraction

(FF) and N.P.N. for the three hypoplastic experimental dogs.

\begin{tabular}{|c|c|c|c|c|c|c|c|c|}
\hline Dog & & Age & $\begin{array}{r}\text { Cln } n \\
\text { per kg }\end{array}$ & $\begin{array}{l}\text { al/min. } \\
\text { per sq. m. }\end{array}$ & $\begin{array}{r}\text { CPAH } \\
\text { per kg }\end{array}$ & $\begin{array}{l}\mathrm{ml} / \mathrm{min} . \\
\text { per sq. } \mathrm{m} .\end{array}$ & $\mathbf{F F}$ & $\begin{array}{c}\text { Non-pro- } \\
\text { tein nitro- } \\
\text { gen mg/ } \\
100 \mathrm{ml}\end{array}$ \\
\hline \multirow[t]{3}{*}{$I: 1$} & 8 & months & 3.91 & 79.92 & 14.18 & 290 & 0.26 & 30 \\
\hline & 11 & , & 1.42 & 29.93 & 9.0 & 187 & 0.13 & 38 \\
\hline & 15 & , & \multicolumn{4}{|c|}{ Almost complete cessation of renal function } & & 106 \\
\hline \multirow[t]{2}{*}{ II $: 4$} & 7 & months & 2.91 & 59.48 & 13.64 & 278 & 0.22 & 29 \\
\hline & 10 & , & \multicolumn{5}{|c|}{ Almost complete cessation of renal function } & 160 \\
\hline \multirow[t]{4}{*}{$y: 7$} & 4 & months & 4.24 & 74.27 & 16.21 & 283 & 0.28 & 29 \\
\hline & 8 & , & 3.33 & 58.0 & 14.36 & 250 & 0.23 & 32 \\
\hline & 10 & 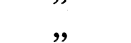 & 2.34 & 42.23 & 12.13 & 219 & 0.20 & 40 \\
\hline & 16 & , & \multicolumn{5}{|c|}{ Almost complete cessation of renal function } & 85 \\
\hline
\end{tabular}

It will be seen from Table 6 that renal function is greatly impaired at those times when there is a rise in N.P. N. For this reason clearance determinations in the clinical material were made only in two dogs, $888 / 56$ and $313 / 58$. The clearance values for the latter one are given as an example:

$\mathrm{C}_{\text {In }}: \quad 0.28 \mathrm{ml} / \mathrm{min} . / \mathrm{kg}$ body-weight or $5.07 \mathrm{ml} / \mathrm{min} . / \mathrm{sq} . \mathrm{m}$. surface;

$\mathrm{C}_{\mathrm{PAH}}: 1.06 \mathrm{ml} / \mathrm{min} . / \mathrm{kg}$ body-weight or $19.56 \mathrm{ml} / \mathrm{min} . / \mathrm{sq} . \mathrm{m}$. surface:

FF : $\quad\left(\mathrm{C}_{\mathrm{I}_{\mathrm{n}}} / \mathrm{C}_{\mathrm{PAH}}\right): 0.26$.

In $\operatorname{dog} 888 / 56$, as well as in $\operatorname{dogs} I: 1$, II : 4 and $V: 7$ at their last clearance determinations, renal function was so greatly impaired that the plasma-levels of inulin and PAH rose to such an extent that the clearance values cannot be considered to be correct and, therefore, are not published.

The result of intravenous urography was negative at elevated N. P. N. levels, that is, no nephrographic effect was obtained. The excretion of diodone decreases simultaneously with the active tubular excretion.

By lowering the blood-pressure by means of inhalation of amyl nitrite a very good nephrographic effect was obtained at urography. We had hoped that by using Krook's method. demonstrated on an autopsy material, for measuring the renal cortex and marrow and calculating the proportional relation between 
them, we would be able to distinguish hypoplastic kidneys at an early stage. But it was found difficult to perform the measurements correctly in the radiographs, and so the method is to be considered too unreliable.

On a few occasions intravenous urography was done under lowering of the blood-pressure immediately after completed determinations of TmPAH (maximal tubular excretion capacity for PAH). The blood-concentration of PAH was high on these occasions, exceeding $20 \mathrm{mg}$ per $100 \mathrm{ml}$. In these cases the nephrographic effect failed to appear. In Fig. 1 the radiographs show the nephrographic effect at ordinary intravenous urography, at urography after lowering of blood-pressure and after blocking of the tubular function with PAH.

The radiographical examinations of the bones showed decreased radiopacity of some parts of the skeleton. This applies particularly to the mandible.

The autopsy findings are recorded in Table $7 .^{1}$ )

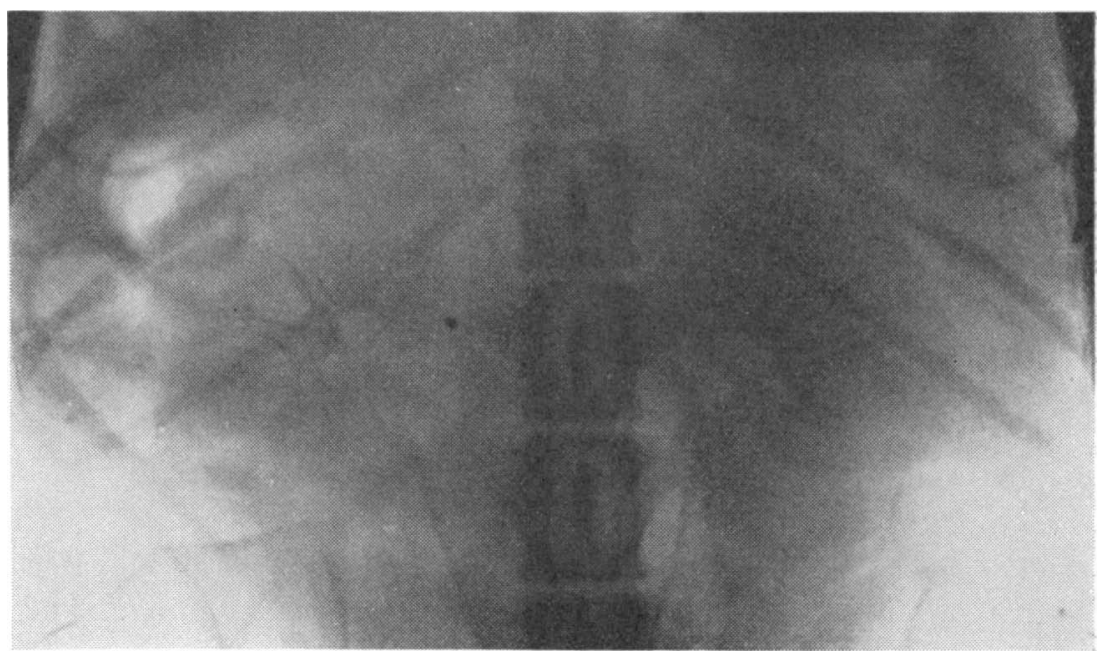

Fig. 1. Intravenous urography:

a) ordinary urography

1) The autopsies were performed in the Department of Pathology at the Royal Veterinary College. 


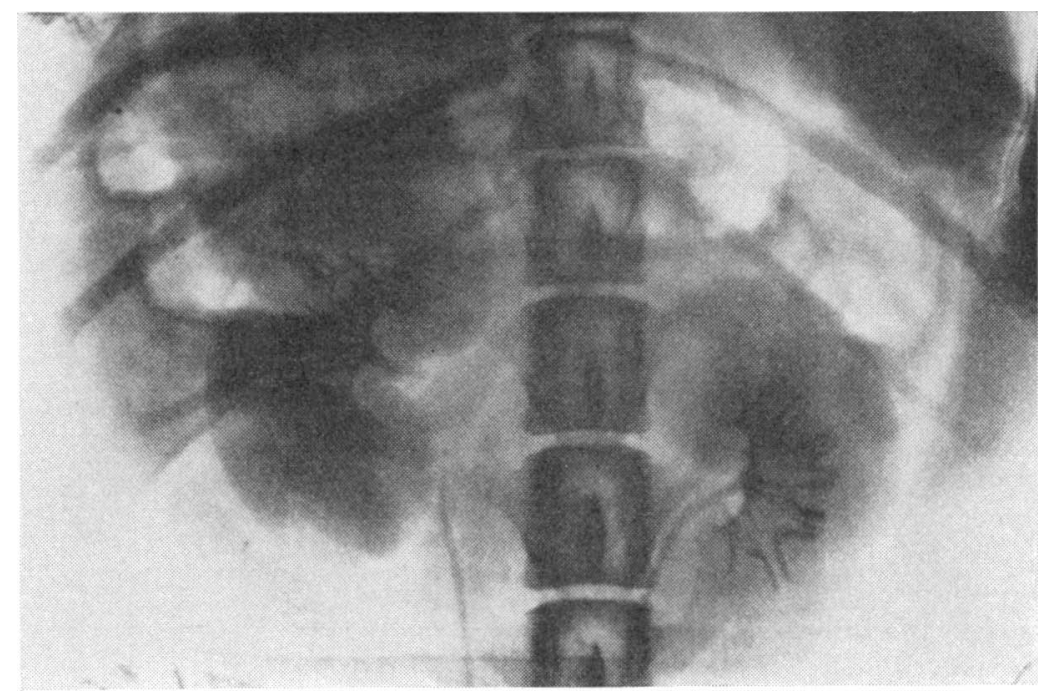

b) after lowering of blood-pressure

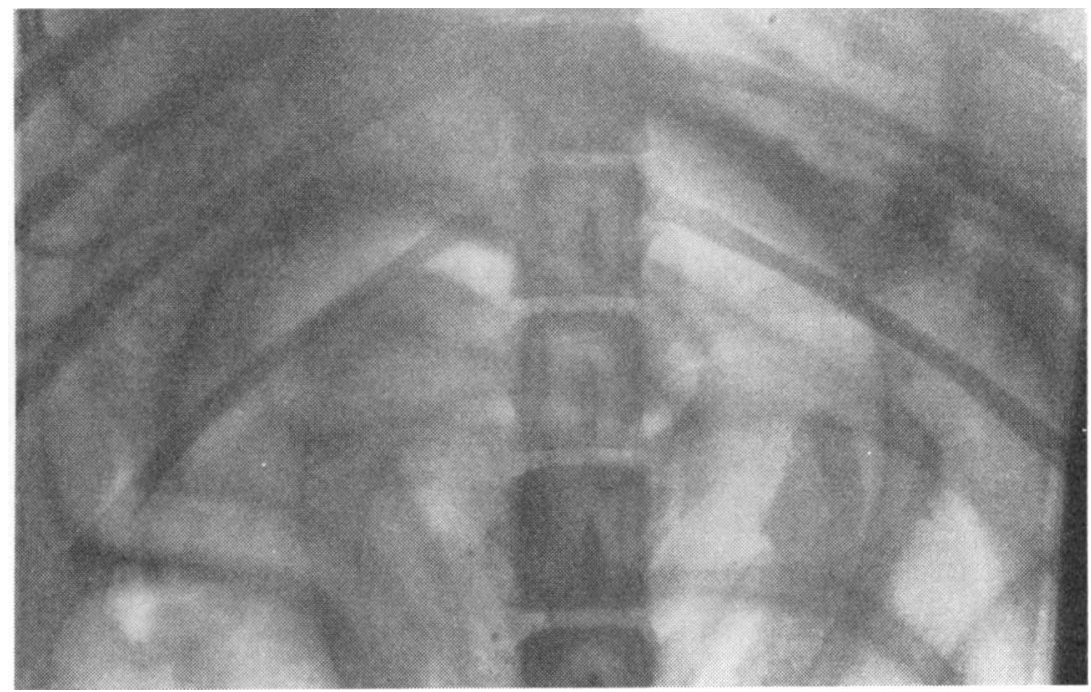

c) after blocking of tubular function by $\mathrm{PAH}$ 
Table 7.

Findings at autopsy of the 17 hypoplastic dogs.

\begin{tabular}{|c|c|c|c|c|c|c|c|c|c|c|c|c|c|c|c|c|c|}
\hline Autopsy findings & 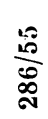 & $\begin{array}{l}0 \\
\stackrel{0}{10} \\
\infty \\
\infty \\
\infty\end{array}$ & 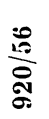 & \begin{tabular}{l}
0 \\
$\frac{0}{0}$ \\
\multirow{0}{0}{} \\
0
\end{tabular} & $\frac{\hat{\sigma}}{\hat{\sigma}}$ & $\underset{\infty}{\tilde{\infty}}$ & $\begin{array}{l}\frac{\sqrt{a}}{\sigma} \\
\stackrel{\sigma}{g} \\
\approx\end{array}$ & 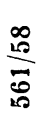 & $\frac{\infty}{\stackrel{p}{\rho}}$ & $\frac{\stackrel{I}{\circ}}{\stackrel{\circ}{\circ}}$ & 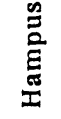 & $\frac{8}{8}$ & $\begin{array}{l}8 \\
8 \\
01\end{array}$ & $\begin{array}{l}\stackrel{g}{+} \\
z\end{array}$ & $\ddot{-}$ & 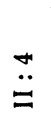 & $\stackrel{\pi}{\ddot{z}}$ \\
\hline $\begin{array}{l}\text { Renal cortical } \\
\text { hypoplasia }\end{array}$ & $x$ & $x$ & $x$ & $x$ & $x$ & $x$ & $x$ & $x$ & $x$ & $x$ & $x$ & $x$ & $x$ & $x$ & $x$ & $x$ & $x$ \\
\hline $\begin{array}{l}\text { Chronic interstitial } \\
\text { nephritis }\end{array}$ & $x$ & & $\times$ & & & $x$ & & $x$ & $x$ & & & & & $x$ & $x$ & $x$ & \\
\hline Nephrosclerosis & & $\times$ & & $x$ & $x$ & & & & & & & & & & & & \\
\hline $\begin{array}{l}\text { Chronic gastritis } \\
\text { Eccentric hyper- }\end{array}$ & $x$ & $x$ & $x$ & $x$ & $x$ & $x$ & $x$ & $x$ & $x$ & $x$ & $x$ & & $x$ & $x$ & $x$ & $x$ & $x$ \\
\hline trophy of the heart & $x$ & $x$ & $x$ & $x$ & $x$ & $x$ & $x$ & & $\times$ & $x$ & $x$ & $x$ & $x$ & $\times$ & $x$ & & $x$ \\
\hline $\begin{array}{l}\text { Myocarditis } \\
\text { Fatty degenera- }\end{array}$ & $x$ & $\times$ & $x$ & & & & $x$ & & & & & & & & & $x$ & \\
\hline $\begin{array}{l}\text { tion of the heart } \\
\text { Hyperaemia and em- }\end{array}$ & & & & & $x$ & & & & & & & & $x$ & $\times$ & & & \\
\hline $\begin{array}{l}\text { physema in the lungs } \\
\text { Hyperplasia of }\end{array}$ & & $x$ & $x$ & $x$ & $x$ & $x$ & $x$ & $x$ & $x$ & $x$ & & & $x$ & & $x$ & & \\
\hline the parathyroid & $x$ & $x$ & $x$ & $x$ & $x$ & $x$ & $x$ & $x$ & $x$ & $x$ & & & $x$ & $\times$ & $x$ & $x$ & $x$ \\
\hline Calcinosis & & $x$ & $x$ & & & $x$ & $x$ & $x$ & $x$ & $x$ & & $x$ & $x$ & $x$ & $x$ & $x$ & $x$ \\
\hline $\begin{array}{l}\text { Osteitis fibrosa } \\
\text { Generalized }\end{array}$ & & $x$ & $x$ & & & & & $\times$ & $x$ & & & & & & $x$ & $x$ & \\
\hline anaemia & & $x$ & & & & & & & & & $x$ & & & $x$ & & & \\
\hline
\end{tabular}

Table 8 is a comparison of the serum-calcium level and the calcinosis demonstrated at autopsy.

T a b l e 8.

Comparison between serum-calcium level and presence of calcinosis demonstrated at autopsy in 15 dogs with renal cortical hypoplasia.

\begin{tabular}{lrc}
\hline \multicolumn{1}{c}{ Dog } & Ca mg/100 ml & Calcinosis \\
\hline $888 / 56$ & 11.4 & $\times$ \\
$920 / 56$ & 6.2 & $\times$ \\
$1040 / 56$ & 6.3 & - \\
$316 / 57$ & 4.3 & - \\
$318 / 57$ & 7.1 & $\times$ \\
$1109 / 57$ & 6.8 & $\times$ \\
$561 / 58$ & 14.3 & $\times$ \\
$604 / 58$ & 8.5 & - \\
Hampus & 4.8 & $\times$ \\
$160 / 60$ & 11.1 & $\times$ \\
E 60 & 11.3 & $\times$ \\
N 49 & 8.4 & $\times$ \\
I $: 1$ & 7.9 & $\times$ \\
II $: 4$ & 6.1 & $\times$ \\
V : 7 & 4.7 &
\end{tabular}




\section{DISCUSSION}

The normal values for serum-electrolytes, red-cell count and haemoglobin concentration recorded in Table 4 are in good agreement with those given in the literature by Carr and Schloerb (1959).

The pathophysiology of renal cortical hypoplasia (Krook) or of any other chronic nephropathy in dogs is explained according to three different principles: changes caused by the uraemia, changes caused by the hyperparathyreoidism, and changes caused by hypertension. The mechanism of the development of hyperparathyreoidism can be explained as follows.

Phosphates are normally excreted by the glomerular filtration, but the tubules, too, co-operate both by absorption in the proximal tubules and by active excretion in distal tubules (Nicholson and Shepherd, 1959). Nicholson (1959) has recently shown that the renal action of parathyroid hormone is on the distal tubules and that it acts by stimulating the tubular excretion of phosphate. In renal cortical hypoplasia the number of glomeruli is probably markedly reduced. In addition tubular changes soon develops. These factors cause diminished excretion of phosphate, which leads to hyperphosphataemia. This is accompanied by hypocalcaemia.

The question of how the latter arises has been much debated. Earlier it was considered that, since excretion of phosphate could not occur via the kidneys, increased elimination would take place through the intestinal mucosa (Mitchell, 1930). The phosphates would thus be brought into contact with the calcium in the intestine and form inabsorbable calcium phosphate, resulting in severe calcium loss leading to hypocalcaemia (Brodey, 1954, and Niemand, 1954). Nowadays it is believed that hypocalcaemia is a direct result of the hyperphosphataemia, since these two substances react according to Guldberg-Waage's law which says that the product of the ion concentrations is constant (Albright and Reifenstein, 1948). It is now considered established that the change of the calcium-phosphate balance is what causes hyperplasia of the parathyroid. What directly regulates the parathyroid activity has been and is still a matter of controversy, the point at issue being whether it is the hyperphosphataemia or the hypocalcaemia that primarily increases parathyroid activity. The question has yet not been fully settled, but in a paper of 1954 Engfeldt et al. point out that the blood-phosphorus content can 
hardly be thought to be the primary regulating agency, but that blood-calcium or some fraction thereof is possibly the primary factor concerned in the regulation. An increased parathyroid activity thus brought about tries to accelerate the excretion of phosphate through the kidneys but fails. Bone-calcium is mobilized and hence the well-known osteodystrophy arises. According to Albright and Reifenstein the mobilization of bone-calcium would change the hypocalcaernia into hypercalcaemia, which in turn would be the cause of the metastatic calcification in various organs. This is also emphasized by Krook.

The secondary hyperparathyreoidism in dogs has hitherto been described mainly patho-anatomically. Hare (1934) was the first to observe the chronic nephritis associated with osteoporosis, which histologically was osteitis fibrosa. He also observed hyperplasia of the parathyroid. Reports of the disease have later been published by Eichholtz and Ojemann (1941), Platt (1951), Brodey (1954), Nielsen and McSherry (1954), Trevino (1955) and Kretzschmar (1956). Brodey, Nielsen and McSherry, and Trevino report one case each, in which laboratory investigations were also done. Examination of blood specimens showed in all cases hyperphosphataemia, hypocalcaemia and relative and absolute anaemia.

The results of our blood-calcium and blood-phosphorus determinations agree with those obtained by the above-named authors. The hypercalcaemia mentioned in the foregoing (Albright and Reifenstein, Krook), however, was not observed in any of our cases. Niemand reports that in $13 \mathrm{dogs}$ he had seen the combination anaemia, osteoporosis and nephritis, but that he had never noted a raised blood-calcium level. In Table 8 comparisons are given between the serum-calcium level and calcinosis demonstrated at autopsy. It will be seen that calcinosis is present without demonstrable hypercalcaemia. This favours the presence of dystrophic calcification rather than calcium metastases. To demonstrate morphologically the difference between these two types of calcification is considered to be very difficult (Kretzschmar). That hypercalcaemia is, nevertheless, present in some forms of renal disorder seems to have been shown, for instance by Gärtner (1956). In a series of dogs used by Lannek (1949) in his studies of the electrocardiogram in uraemic cases the presence of hypercalcaemia was also suggested by, for instance, the fact that elongation of the Q-T interval was not very common. 
In accordance with our studies, elongation of the Q-T interval is, in fact, seen in dogs with hypocalcaemia in combination with hyperphosphataemia. In Lannek's series curved ST segments are fairly often seen, similarly to those obtained by us in experimentally induced hypercalcaemia in a dog. These two factors suggest that the dogs in Lannek's material did not have hypocalcaemia but very probably hypercalcaemia.

A few authors, for example Krook, assert that dogs with marked azotaemia pathologically show less extensive calcinosis than do dogs with lower non-protein-nitrogen values. This has not been verified by our investigations.

The lowest serum-calcium level, $4.3 \mathrm{mg}$ per $100 \mathrm{ml}$, was recorded in $\operatorname{dog} 316 / 57$. This dog, as well as no. 286/55, had attacks of convulsion of a severe nature. Unfortunately, electrolyte determinations are lacking in the latter case, but very probably this dog, too, had low calcium values, which is indicated by the fact that the electrocardiogram showed highly significant elongation of the Q-T interval.

It will be seen from Tables 2,4 and 5 that the serumpotassium levels were raised in a great number of cases. A spontaneous clinical hyperkalaemia appears when the excretion of potassium through the kidneys is reduced or has ceased altogether, or when there is a rapid release of potassium from the cells. Potassium is excreted through the kidneys by glomerular filtration and active tubular excretion. The renal excretion of potassium may be low in chronic renal disease, but it is not reduced to the same extent as the glomerular filtration and, in fact potassium clearance has been found to exceed inulin clearance (Leaf and Camara, 1949; Platt, 1950). For this reason significant hyperkalaemia is exceptional in uraemia. In our material the development of hyperkalaemia is to be considered due to a combination of reduced excretion of potassium and increased transport of potassium from the cells to the extracellular fluid because of the acidosis accompanying the renal damage.

Potassium intoxication is actually a very serious condition. A rise of serum-potassium to $47 \mathrm{mg}$ per $100 \mathrm{ml}$ or more in dogs leads to death from heart-block (Winkler, Hoff and Smith, 1938; Bellet, 1954). The potassium intoxications seem to be the immediate cause of death after bilateral nephrectomy (Smith, 1951).

That a chronic renal disease is often associated with anaemia is now a known fact. In man (Spühler and Zollinger, 1953) the 
anaemia is considered to be a very important symptom and one of the first to appear in renal disease. The anaemia has also been observed in dogs by some authors (Hare, 1934; Hogg, 1948; Nielsen and McSherry, 1954; Brodey, 1954; Paplanus, 1958). In an investigation of the blood picture in 30 dogs with renal disease Bonani (1959) found an average of 5600000 red cells per c.mm and quoted this as a low value. The average value for haemoglobin concentration was slightly high and Bonani therefore considers that these dogs had hyperchromaemia.

In our material, as will be seen from Tables 4 and 5 , there was a very probable $(0.01>\mathrm{P}>0.001)$ decrease of the number of red cells per c.mm as well as a decrease of the haemoglobin concentration; there was also a lowering of the haematocrit values. Among the 19 dogs anaemic mucons membranes were noted clinically in 8 . In some cases the anaemia was noticeable even at autopsy. In contradistinction to Bonani's conclusions our observations seem to imply that on a morphological basis the anaemia is rather to be classified as a "simple microcytic anaemia" (Harrison et al., 1958). More recent works (Forssell, 1958; Naetz, 1958) have shown that the cause of anaemia in chronic renal disorders is the reduced production of erythropoietin, a substance formed in the kidneys and whose function is to stimulate bone-marrow activity. The production of erythropoietin is stimulated by different forms of anoxia.

The failure of obtaining a nephrographic effect at intravenous urography, when there was a high concentration of PAH in the blood (above $20 \mathrm{mg}$ per $100 \mathrm{ml}$ ) is a practical example illustrating the so-called competitive effect which two or more substances removed by active excretion in the renal tubules may exert on one another (Smith, Goldring and Chasis, 1938; Josephson and Kallas, 1953). The nephrographic effect at urography is produced by accumulation of the contrast medium in the cells and ducts of the renal tubules. Several different factors govern the tubular transport mechanism, which is essential to the tubular excretion. Accordingly, at a high concentration of $\mathrm{PAH}$ in the kidney tubules simultaneous transport of diodone is prevented and so no or reduced nephrographic effect is obtained. 


\section{REFERENCES}

Albright, $F$. and Reifenstein, E. C., Jr.: Parathyroid glands and metabolic bone disease. Baltimore, 1948, p. 116.

Bellet, S.: Physiopathologie du Potassium. Paris 1954, p. 67.

Bonani, V.: Nuova Vet. 1959, 35, 53.

Brodey, R. S.: J .Amer. vet. med. Ass. 1954, 124, 275.

Carr, M. H. and Schloerb, P. R.: J. Lab. Clin. Med. 1959, 53, 646.

Clark, E. P. and Collip, J. B.: J. biol. Chem. 1925, 63, 461.

Dyrendahl, $S$. and Henricson, B.: Personal communication.

Eichholtz, P. G. and Ojemann, J. G.: Ned. T. Geneesk. 1941, 85, 2218.

Engfeldt, B., Hjertquist, S. O. and Strandh, J. R. E.: Acta endocr. (Kbh.) 1954, 15, 119.

Forssell, J.: Acta med. scand. 1958, 161, 169.

Gärtner, K.: Mh. Vet.-Med. 1956, 11, 479.

Hare, T.: Proc. roy. Soc. Med. 1934, 29:2, 789.

Harrison, T. R., Adams, R. D., Bennett, I. L., Reswik, W. H., Thorn, G. W. and Wintrobe, M. M.: Principles of internal medicine. 3rd ed., 1958, Mc Gram-Hill Book Comp. Inc., p. 210.

Hogg, A. H.: Vet. Rec. 1948, 60, 117.

Josephson, B. and Kallas, J.: Amer. J. Physiol. 1953, 174, 65.

Kramer, B. and Tisdall, F. F.: J. biol. Chem. 1921, 47, 475.

Kretzschmar, Ch.: Tierärztl. Umsch. 1956, 11, 12.

Krook, L.: Acta path. microbiol. scand. Suppl. 122, 41, 1957.

Lannek, N.: A clinical and experimental study on the electrocardiogram in dogs. Stockholm 1949.

Leaf, A. and Camara, A. A.: J. Amer. med. Ass. 1949, 155, 1204.

Mitchell, A. G.: Amer. J. Dis. Child. 1930, 40, 345.

Naetz, J. P.: Nature 1958, 182, 1516.

Nicholson, T. F.: Canad. J. Biochem. Physiol. 1959, 37, 113.

Nicholson, T. F. and Shepherd, G. W.: Canad. J. Biochem. Physiol. 1959, 37, 103.

Nieberle, $K$. und Cohrs, P.: Lehrbuch der Spez. Path. Anat. d. Haust., Jena, 1954, p. 26.

Nielsen, S. W. and McSherry, B. J.: J. Amer. vet. med. Ass. 1954, 124, 270.

Niemand, H. G.: Tierärztl. Umsch., 1954, 9, 89.

Raplanus, S. H., Zbar, M. J. and Hays, J. W.: Amer. J. Path. 1958, 34, 149.

Platt, H.: J. comp. Path. 1951, 61, 140, 188 \& 197.

Platt, R.: Clin. Sci. 1950, 9, 367.

Smith, H. W.: The Kidney. Oxford University Press, N. Y. 1951, p. 630.

Smith, H. W., Goldring, W. and Chasis, H.: J. Clin. Invest., 1938, 17, 263.

Spühler, O. and Zollinger, H. U.: Z. klin. Med. 1953, 151, 1.

Taussky, H. H. and Shorr, E.: J. biol. Chem. 1953, $202,675$.

Trevino, G. S.: The Southw. Vet. 1955, 8, 338.

Winkler, A. W., Hoff, H. E. and Smith, P. K.: Amer. J. Physiol. 1938, 124, 478. 
Äsheim, Å., Persson, F. and Persson, S.: Renal clearance in dogs with regard to variations according to age and sex. Acta physiol. scandinav. In press.

\section{SUMMARY}

The clinical picture of renal cortical hypoplasia in the dog has been studied. Blood analyses including the electrolytes sodium, potassium, calcium and phosphorus are reported in detail. Hyperkalaemia, hypocalcaemia and hyperphosphataemia are present in hypoplastic dogs. Hypercalcaemia, on the other hand, is not seen, and the calcinosis in renal disorders is therefore considered to be caused by dystrophic calcification and not by metastases. The causation of the secondary hyperparathyreoidism is discussed. The presence of anaemia is demonstrated. Finally, a practical example is given to illustrate the competitive effect in the renal tubules between para-amino-hippuric acid $(\mathrm{PAH})$ and diodone.

\section{ZUSAMMENFASSUNG \\ Nierenrindehypoplasie beim Hunde. Ein klinisches Studium über Urämie und sekundären Hyperparathyreoidismus.}

Das klinische Bild der Nierenrindehypoplasie beim Hunde wurde studiert. Úber die Blutuntersuchungen einschliesslich die Untersuchungen der Elektrolyten Natrium, Kalium, Kalzium und Phosphor wurde eingehend berichtet. Es besteht eine Hyperkaliämie, Hypocalcämie und Hyperphosphatämie. Dagegen in keinem Fall wurde eine Hypercalcämie beobachtet, weswegen man annimmt dass eine Verkalkung bei Nierenschädigungen durch dystrophische und nicht durch metastatische Verkalkung zustandekommt. Die Etiologie des bestehenden Hyperparathyreoidismus wurde besprochen. Auf das Vorkommen von Anämie wurde hingewiesen. Schliesslich wurde ein anschauliches Beispiel über konkurrierenden Effekt zwischen Paraaminohippursäure $(\mathrm{PAH})$ und Diodon in den Nierentubuli angeführt.

\section{SAMMANFATTNING}

Njurbarkshypoplasi hos hund. En klinisk studie över uremin och den sekundära hyperparathyreoidismen.

Den kliniska bilden vid njurbarkshypoplasi hos hund har studerats. Blodundersökningar även omfattande elektrolyterna $\mathrm{Na}, \mathrm{K}, \mathrm{Ca}$ och $P$ redovisas $i$ detalj. Hyperkaliämi, hypocalcämi och hyperfosfatämi föreligger. Däremot har aldrig hyperkalcämi iakttagits, varför calcinosen vid njurskador anses vara orsakad av dystrofisk förkalkning och ej av kalkmetastaser. Etiologin till den föreliggande hyperparathyreoidismen diskuteras. Förekomsten av anämi påvisas. Slutligen ges ett praktiskt åskådliggjort exempel på competition effekt i njurtubuli mellan paraaminohippursyra (PAH) och diodon. 